\title{
粉炭の堆積体内部における蓄熱過程ならびに 自然発火し得る粉炭量の計算*
}

常温付近における石炭の自然発火発生機構に関する研究（第 2 報）

\author{
伊木正二 \\ 樋口澄 志
}

\section{1. 緒言}

常温付近で石炭と空気とが接触した場合に発生する酸 化発熱量を測定し，その発熱量の蓄積のみで自然発火が 起こり得る石炭の量を理論的に計算した例，ならびにそ の計算に基ら゙いて実験的に常温付近から自然発火を起こ させた例はこれまでなかつた。石炭の堆積体内部におけ る蓄熱過程ならびに自然発火を起こし得る石炭の量が明 らかになれば，実際に自然発火の予防气の他の対策に役 立つばかりでなく，実験的にいつでも計画したとおり自 然発火を起こし得るようになることは，石炭の自然発火 現象をより明確に把握するらえにまた早期発見法，予防 法, 消火法などの実用的技術を開発するうえに有効な手 段となり得るものと考えられる。

著者らは前報”において，20 $65^{\circ} \mathrm{C}$ とららいが低温 域に扔いて $48 \mathrm{mesh}$ 以下の粉炭と空気が接触反応した場 合の単位時間当り酸化発熱量を測定した結果について報 告した。その結果によれば，20 $65^{\circ} \mathrm{C} に$ おける粉炭の酸 化発熱量は炭種によって異なり, 温度の関数として近似 的に Arrhenius の式で表現され，温度の上昇にともな つて指数関数的に増大寸ることが明らかになつた。本報 では粉炭堆積体の内部における酸化熱の蓄積が自然発火 の根本原因であるという基本的な立場をとつた場合に， 自然発火し得る最低限の粉炭量はどの位か，また蓄熱の 過程はどのような経過をたどるかについて理論的な考察 および計算を行なう。

\section{2. 粉炭堆積体内部での熱収支と酸素収支}

石炭の自然発火現象を理論的に考察する場合，石炭と いら物質ならびに発火の根本原因をどのように考えるか といらことが重要な問題である。炭鉱の坑内で自然発火 が起こりやすい場所としては, 累層㧍よび厚層の採掘箇 所, 断層しゅう曲の多い所, 高落箇所, 採掘跡の充填や 密閉が不十分な所などがあげられる。これらの各箇所に 共通した点は, 石炭が地圧などによつて粉化されやすい 場所かまたは何かの原因ですでに粉化してしまつている

* 1973年11月 5 日受理 昭和46年 4 月 1 日 日本鉱業会春季大会飞批いて発表

1. 正会員 工博 東京大学教授 工学部資源開発工学科

2. 正会員 工博 北海道大学助手 丁学部資源開発工学科
場所ということである。

また石炭と空気とが常温付近で接触した場合の発熱の 原因っまり自然発火の原因については，古くから多数の 研究が行なわれてきた。歴史的に見ると，バクテリヤ， 硫黄, 燐, 水分の作用などがあげられたが，現在では石 炭の酸化熱が根本原因であると一般に認められている。

したがって本研究では, 石炭組織と空気中の酸素の結 合による酸化熱が原因となり，粉化した石炭の堆積体内 部での蓄熱が自然発火を発生させるといら基本的な立場 をとつて理論計算を行なう。炭層中に存在する特殊な 「はさみ」や石炭組織, むしくは亀裂中に偏在する鈗物 質などが自然発火の直接原因であり得た場合，または生 化学的発熱や地圧による摩擦熱, 圧縮熱乞の他の局所的 な発熱源が原因となる自然発火を取り扱ら場合には，考 方を変える必要がある。

\section{$2 \cdot 1$ 熱収支}

まず粉炭の堆積体に空気を通じた場合の熱収支に関し て考察する。ただし以下の考察に扔いては常温付近での 粉炭堆積体に㧍ける自然発火過程をモデルとして考元て いるので, 粉炭による空気中の酸素の吸収はさほど顕著 ではなく，蓄熱の進行して行く過程で必要な通気量は少 量であると考え, 粉炭粒子と通気との温度は等しいもの とする ${ }^{2}$ 。また粉炭粒子層を空気が通る際に空気の流れ の方向ならびにそれに直角な方向への熱移動は; 複雑な 幾つかの機構によつて行なわれることが知られている が，粉炭粒子と空気を含めて伝導だけによつて熱が移動 する均一な仮想的固体として扱らこととする。反応工学 の分野 3 ではこの仮想的な熱伝導率を有效熱伝導率 $\left(\lambda_{e}\right)$ と名ら゙けているが，著者らは前報”に执いて常温付近に おける粉炭の有効熱伝導率の測定を行ない, 通気量の少 ない場合には，他の研究者の測定による通気のない場合 の粉炭の熱伝導率と大差ないことを確かめているので, 粉炭堆積体内部注いては, 有效熱伝導率は方向によっ て変らないと仮定することにする。

第 1 図のような数学的に 1 次元の場合の微小容積 $d L$ $d S$ について熱収支を考光ると, $d t$ 時間中にこの微小容 積 $d L d S$ 内に蓄積する総括の熱量 $Q(\mathrm{cal})$ は， $\varepsilon$ を空隙 率として次のように表わされる。 


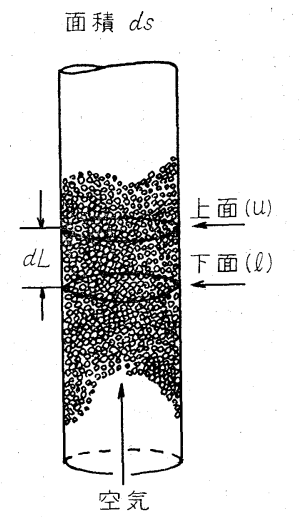

上面での温度 $T+\frac{\partial T}{\partial L} d L\left({ }^{\circ} \mathrm{C}\right)$

下面での温度 $T\left({ }^{\circ} \mathrm{C}\right)$

有効熱伝澊率 $\lambda_{e}\left(\mathrm{cal} \cdot \mathrm{cm}^{-1} \cdot \mathrm{sec}^{-1}\right.$

$\left.\cdot \operatorname{deg}^{-1}\right)$

空気の比熱 $S_{f}\left(\mathrm{cal}^{-} \mathrm{g}^{-1} \cdot \mathrm{deg}^{-1}\right)$

空気 $の$ 密度 $\rho_{f}\left(\mathrm{~g} \cdot \mathrm{cm}^{-3}\right)$

石峞 の比熱 $S_{c}\left(\mathrm{cal} \mathrm{g}^{-1} \cdot \operatorname{deg}^{-1}\right)$

石炭の密度 $\rho_{c}\left(\mathrm{~g} \cdot \mathrm{cm}^{-3}\right)$

空気の筀塔質量流量 $G\left(\mathrm{~g} \cdot \mathrm{sec}^{-1} \cdot \mathrm{cm}^{-2}\right)$

\section{第1図}

粉炭堆積体に空気を通じた場合の熱 収支

$$
Q=S_{f} \rho_{f} \varepsilon d T d L d S+S_{c} \rho_{c}(1-\varepsilon) d T d L d S
$$

熱伝導によつて微小容積 $d L d S$ の下面を通じて流入す る熱量は，下面加上上面方向へ流れる熱量を正とすると

$$
q_{l}=-\lambda_{e} \frac{\partial T}{\partial L} d S d t
$$

で表わされ，同様に上面から流出する熱量は

$$
q_{u}=-\lambda_{e} \frac{\partial}{\partial L}\left(T+\frac{\partial T}{\partial L} d L\right) d S d t
$$

で表わされる。微小容積 $d L d S$ 内に蓄積する熱量は, 流 入する熱量から流出する熱量を引いて次のようになる。

$$
q_{l}-q_{u}=\lambda_{e} \frac{\partial^{2} T}{\partial L^{2}} d L d S d t
$$

空気の流れに伴うエンタルピー $q^{\prime}$ は, 下面では

$$
q_{l}^{\prime}=S_{f} G T d S d t
$$

上面では

$$
q^{\prime}=S_{f} G\left(T+\frac{\partial T}{\partial L} d L\right) d S d t
$$

で表わされ，微小容積 $d L d S$ 内に蓄積する熱量は

$$
q_{l^{\prime}}-q_{u^{\prime}}=-S_{f} G \frac{\partial T}{\partial L} d L d S d t
$$

で表わされる。

微小容積 $d L d S$ 内で粉炭粒子が空気中の酸素と反応 することによつて発生する熱量 $q^{\prime \prime}$ は, 粉炭堆積体の体積 を基準とした見かけの反応速度を $r^{\prime}\left(\mathrm{mol} \cdot \mathrm{sec}^{-1} \cdot \mathrm{cm}^{-3}\right)$ とし，見かけの反応熱を $\Delta H\left(\mathrm{cal} \cdot \mathrm{mol}^{-1}\right)$ とすれば,

$$
q^{\prime \prime}=r^{\prime} \Delta H d L d S d t
$$

で表わされる。

微小容積 $d L d S$ の総括の蓄積熱量は (1) 式で表わさ れ，熱伀導による熱 (4) 式と空気の流れによるエンタル ピー（7) 式と化学反応熱 (8) 式との和に等しいので (9) 式を得る。

$$
\begin{array}{r}
\frac{\partial T}{\partial t}\left[S_{f} \rho_{f} \varepsilon\right. \\
\left.+S_{c} \rho_{c}(1-\varepsilon)\right]=\lambda_{e} \frac{\partial^{2} T}{\partial L^{2}} \\
-S_{f} G \frac{\partial T}{\partial L}+r^{\prime} \Delta H \cdots \cdots
\end{array}
$$

ここで $S_{f} \rho_{f} \varepsilon+S_{c} \rho_{c}(1-\varepsilon)=S_{m} \rho_{m}$

とおくと

$$
S_{m} \rho_{m} \frac{\partial T}{\partial t}=\lambda_{e} \frac{\partial^{2} T}{\partial L^{2}}-S_{f} G \frac{\partial T}{\partial L}+r^{\prime} \Delta H
$$

となる。(11)式が数学的に 1 次元の場合の粉炭堆積体内 部の熱収支を表わす基礎式であるが，同様にして，3 次 元の場合にはベクトル記号で

$$
\begin{aligned}
S_{m} \rho_{m} \frac{\partial T}{\partial t} & =\operatorname{div}\left(\lambda_{e} \operatorname{grad} T\right)-\operatorname{div}\left(S_{f} G T\right) \\
& +r^{\prime} \Delta H \ldots \ldots \ldots \ldots \ldots \ldots \ldots \ldots \ldots \ldots \ldots \ldots \ldots \ldots \ldots \ldots \ldots \ldots \ldots
\end{aligned}
$$

と表わせる。

\section{$2 \cdot 2$ 酸素収支}

前節の熱移動と同様な式が粉炭堆積体内部における酸、 素の移動についても得られる。酸素の消費量は拡散と空 気の流れによるものと化学反応によるものとの和に等し いから，分子拡散ならびに乱流拡散の両方の因子を考慮 に入れた有効桩散係数を $D_{e}\left(\mathrm{~cm}^{2} \cdot \mathrm{sec}^{-1}\right)$, 酸素濃度を $C\left(\mathrm{~mol} \cdot \mathrm{cm}^{-3}\right)$ とすると第 1 図のように数学的に 1 次元 の場合の酸素収支式は，

$$
\begin{aligned}
& \frac{\partial C}{\partial t}=\frac{D_{e}}{G / \rho_{f}} \frac{\partial}{\partial L}\left[\frac{\partial\left(G C / \rho_{f}\right)}{\partial L}\right] \\
& -\frac{G}{\rho_{f}} \frac{\partial C}{\partial L}-r^{\prime}
\end{aligned}
$$

となり, 3 次元の場合には

$$
\frac{\partial C}{\partial t}=\operatorname{div}\left(\frac{D_{e}}{G / \rho_{f}} \operatorname{grad} \frac{G C}{\rho_{f}}\right)-\operatorname{div} \frac{G C}{\rho_{f}}-r^{\prime}
$$

で表わされる。

\section{$2 \cdot 3$ 反応速度式について}

粉炭と空気中の酸素との反応における見かけの反応速 度は，近似的に Arrhenius の式で表現し得ることが多

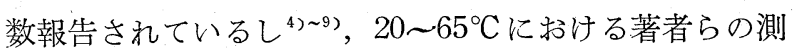
定においてもそのことが確かめられているので'，見か けの頻度係数を $A_{a}\left(\mathrm{~mol} \cdot \mathrm{cm}^{-3} \cdot \mathrm{sec}^{-1}\right)$, 見かけの活性化 エネルギーを $E_{a}\left(\mathrm{cal} \cdot \mathrm{mol}^{-1}\right)$ で表わすと

$$
r^{\prime}=A_{a} e^{-\frac{E_{a}}{R T}}
$$

ただし $R$ は気体定数 $\left(1.98 \mathrm{cal} \cdot \mathrm{deg}^{-1} \cdot \mathrm{mol}^{-1}\right), T$ は絶対 温度で表わされる。

\section{3. 粉炭堆積体内部での蓄熱過程を表現する一般式}

前節までの考察によつて, 粉炭堆積体内部での蓄熱過 程を表現する一般式は, 熱収支式 (12) 式, 酸素収支式 (14)式ならびに反応速度式(15)式であり，これらを連立 方程式として, 適当な境界条件, 初期条件のもとに温度 に関して解けば, 粉炭堆積体内部での蓄熱過程を知るこ とができることになる。

\section{4. 一般式の単純化とそれを解くために必要な定数}

$4 \cdot 1$ 熱収支式および酸素収支式の単純化 
坑内に㧍いては極めて少量の漏風しかない所でも自然 発火が発生していることからも納得できるように，常温 付近での石炭の酸化反応を考える場合には，消費される 酸素量は極めて少量であり, 自然発火が進展して行くう えで必要な通気量は少量でよいと考光られるから, 通気 による熱移動量も少ないものとする。通気による熱移動 を近似的に無視すると，(12)式は単純化されて

$$
S_{m} \rho_{m} \frac{\partial T}{\partial t}=\operatorname{div}\left(\lambda_{e} \operatorname{grad} T\right)+r^{\prime} \Delta H
$$

となる。

常温付近では石炭による消費酸素量が少ないといら同 様な考え方から，粉炭堆積体内で通気系路が極端に長い 場合以外は, 通気中の酸素濃度の低下も近似的にこれを 無視する。その場合には粉炭堆積体内部での酸素濃度は 一定と考元られ，酸素收支の基礎式(14)式そのものを無 視することになる。

\section{$4 \cdot 2$ 最も単純化した基礎式とそれを解くために必要 な定数}

前節での最も単純化した基礎式（16）式に反応速度式 (15)式を代入し， $A_{a} \Delta H=A\left(\mathrm{cal} \cdot \mathrm{cm}^{-3} \cdot \mathrm{sec}^{-1}\right)$ と置く と, 粉炭堆積体内部の蓄熱過程を表現する基礎式は

$$
S_{m} \rho_{m} \frac{\partial T}{\partial t}=\operatorname{div}\left(\lambda_{e} \operatorname{grad} T\right)+A e^{-\frac{E_{a}}{R T}}
$$

となり，これを解くために最低限必要な定数は，粉炭堆 積体の体積比熱 $\left(S_{m} \boldsymbol{\rho}_{m}\right)$, 有効熱伝導率 $\left(\lambda_{e}\right)$, 定数 $(A)$ および見かけの活性化エネルギー $\left(E_{a}\right)$ となる。

\section{5. 基礎方程式の数值解}

\section{$5 \cdot 1$ 基礎方程式}

基礎方程式(17)式を直角座標，円筒座標そして球座標 で表わすと(18), (19)，(20)式のようになる。

$$
\begin{aligned}
& S_{m} \rho_{m} \frac{\partial T}{\partial t}=\lambda_{e}\left(\frac{\partial^{2} T}{\partial x^{2}}+\frac{\partial^{2} T}{\partial y^{2}}+\frac{\partial^{2} T}{\partial z^{2}}\right)+A e^{-\frac{E a}{R T}} \\
& S_{m} \rho_{m} \frac{\partial T}{\partial t}=\lambda_{e}\left(\frac{\partial^{2} T}{\partial r^{2}}+\frac{1}{r} \frac{\partial T}{\partial r}+\frac{\partial^{2} T}{\partial z^{2}}\right)+A e^{-\frac{E_{a}}{R T}} \\
& S_{m} \rho_{m} \frac{\partial T}{\partial t}=\lambda_{e}\left(\frac{\partial^{2} T}{\partial r^{2}}+\frac{2}{r} \frac{\partial T}{\partial r}\right)+A e^{-\frac{E a}{R T} \cdots(19)}
\end{aligned}
$$

ただし， $x, y, z$ は直交座標での軸方向の距離を表わし， $r$ は円筒座標, 球座標での半径方向の距離を表わす。ま た前に述べたように, 通気量が少ない場合の粉炭の有効 熱伝導率 $\left(\lambda_{e}\right)$ は, 通気のない場合の粉炭の熱伝導率と大 差なく，方向によっても変らないものとしている。

\section{$5 \cdot 2$ 境界条件, 初期条件について}

実際に坑内で自然発火が発生している環境は複雑であ り, 個々の場合に押いてその境界条件, 初期条件は違つ ていると考えられるので，一般的に簡単な数式で表わす
ことはできない。しかし実験的に自然発火を起こさせよ らとする場合, もしくは理論的に自然発火を考察する場 合に単純化した熱的境界条件としては

i ) 断熱的境界条件

ii）ニュートンの泠却に基づく境界条件

iii）表面温度一定といら境界条件

などが考光られる。まず断熱的境界条件であるが，実際 の自然発火は少なくとも完全な断熱的状態では起こって おらず，絶売ず幾らかの熱の放散が行なわれる条件下で 起こつていると考えられるので実際的でない。ニュート ンの冷却の法則に基づく境界条件を適用することも可能 ではあるが, この場合には粉炭堆積体の表面熱伝達俰数 の測定が必要となり, 計算を複雑化する。したがつて, 本報では粉炭堆積体の表面温度は内部の温度が上昇して も一定であるという境界条件を採用した。表面温度一定 といら条件は, 粉炭堆積体内部で発生した熱が堆積体の 表面では完全に外部へ逃げてしまらことであるから，実 験的に自然発火を起こすという面からは上記 3 条件の中 では最も起こしにくい条件となるが，実験的に与えやす い条件であるし，粉炭堆積体表面と空気の間での表面熱 伝達係数を求めなくても良いという利点がある。

表面温度一定という境界条件法

$\left.T_{\text {(表面, }} t\right)=T_{\text {(表面, }}, 0$ ) $=T_{0}, t>0$

で表わされる。

初期条件は, 最初の温度は粉炭堆積体全体が $T_{0}$ で一 定であるという意味で

$$
T=T_{0}, t=0 \cdots
$$

で表わされる。

\section{$5 \cdot 3$ 差分近似式}

これまでの考え方で行くと, 粉炭堆積体内部に自然発 火が発生するか否かは, その粉炭の堆積の形状に応じて 基礎式(18), (19)，(20)式のいずれかを条件(21)式，(22) 式のもとに解き, 粉炭堆積体内部に急激な温度上昇をす る部分があるか否かによつて決まることになる。しかし これらの基礎式には発熱項 $\left(A e^{-\frac{E_{a}}{R T}}\right)$ があるために, 解 析的にこれを解くことは難かしい。まず考えられること は指数関数の展開であるが，粉炭の場合 $E_{a} \fallingdotseq 5500 \sim$ $10000\left(\mathrm{cal} \cdot \mathrm{mol}^{-1}\right), R \fallingdotseq 1.98\left(\mathrm{cal} \cdot \mathrm{deg}^{-1} \cdot \mathrm{mol}^{-1}\right), T \fallingdotseq 300$ $\left({ }^{\circ} \mathrm{K}\right)$ 位の值と考元ても, $E_{a} /(R \cdot T) \fallingdotseq 8 \sim 17$ となつて, これを普通に展開しても收れんが悪い。指数項を 1 次式 または 2 次式で近似して解析的に解く方法も幾つか報告 されてはいるが100 13)，ここでは実用上基礎式の微分を 差分で近似し, 大型電子計算機により数值解を求めた。

まず酸化熱の蓄積だけで自然発火に至るには，ぞの位 の量の粉炭が必要かといら目安を得るために, 1 次完的 に扱える球座標に関する基礎式 (20) 式を使用する。 $r$ (半径)方向を刻み $h(=a / M)$ で，また $t$ (時間)を刻み $k$ で刻むことにする。ただし， $a$ は粉炭堆積体(球型)の 
半径であり，Mは刻みの数(区間数)である。 $r$ の值とし ては $0, h, 2 h, \cdots, M h(=a)$ を考え, $t$ の值としては $0, k$, $2 k, \cdots$ 考えることにする。そして一般に

$$
T_{m, n}=T_{(m h, n k)}
$$

とおく。

(20)式の微分を差分で置き換えて

$$
\begin{gathered}
\frac{T_{m, n+1}-T_{m, n}}{k}=C_{1}\left(\frac{T_{m_{-1}, n}-2 T_{m, n}+T_{m+1}, n}{h^{2}}\right. \\
\left.+\frac{2}{m h} \cdot \frac{T_{m+1}, n-T_{m, n}}{h}\right)+C_{2} \exp \left(\frac{-E_{a}}{R T_{m, n}}\right)
\end{gathered}
$$

ただし $C_{1}=\frac{\lambda_{e}}{S_{m} \rho_{m}}, C_{2}=\frac{A}{S_{m} \rho_{m}}$ となる。

$T_{m, n+1}$ に関して整理すると

$$
\begin{aligned}
T_{m, n+1} & =T_{m, n}+k C_{1}\left(\frac{T_{m-1}, n-2 T_{m, n}+T_{m+1}, n}{h^{2}}\right. \\
& \left.+\frac{2}{m h} \frac{T_{m+1}, n-T_{m, n}}{h}\right)+k C_{2} \exp \left(\frac{-E_{a}}{R T_{m, n}}\right)
\end{aligned}
$$

となり, $T_{m-1, n}, T_{m, n}, T_{m+1, n}$ から $T_{m, n+1}$ を求めること ができる。

原点に関して対称であることから, 球の中心 $r=m h=0$ では $\left(\frac{2}{r} \frac{\partial T}{\partial r}\right)$ は不定形をとることになるが, Maclaurin 展開によつて $T^{\prime}(r)=T^{\prime}(0)+r T^{\prime \prime}(0)+\frac{1}{2} r^{2} T^{\prime \prime \prime}(0)+\cdots$ となり， $T^{\prime}(0)=0$ がら $r$ を 0 に近づける時の $\left(\frac{2}{r} \frac{\partial T}{\partial r}\right)$ の極限值は，r=0で $2 \frac{\partial^{2} T}{\partial r^{2}}$ の值になる。したがつて (20) 式は $r=0$ では

$$
S_{m} \rho_{m} \frac{\partial T}{\partial t}=\lambda_{e}\left(3 \frac{\partial^{2} T}{\partial r^{2}}\right)+A e^{-\frac{E_{a}}{R T}}
$$

となり，その差分近似式は

$$
\begin{aligned}
T_{m, n+1} & =T_{m, n}+3 k C_{1}\left(\frac{T_{m_{-1}, n}-2 T_{m, n}+T_{m+1}, n}{h^{2}}\right) \\
& +k C_{2} \exp \left(\frac{-E_{a}}{R T_{m, n}}\right) \cdots \cdots \ldots \ldots \ldots \ldots \ldots \ldots \ldots \ldots \ldots \ldots \ldots \ldots
\end{aligned}
$$

または

$$
\begin{aligned}
T_{m, n+1} & =T_{m, n}+6 k C_{1}\left(\frac{T_{m+1}, n}{h^{2}} T_{m, n}\right. \\
& +k C_{2} \exp \left(\frac{-E_{a}}{R T_{m, n}}\right) \cdots \ldots \ldots \ldots \ldots \ldots
\end{aligned}
$$

と表わせる。

\section{$5 \cdot 4$ 定数值に関する検討}

\begin{tabular}{|c|c|c|c|c|c|c|c|}
\hline 試 料 & 名 & \multicolumn{2}{|c|}{$\mid \begin{array}{l}\lambda_{e}\left(\mathrm{cal} \cdot \mathrm{cm}^{-1}\right. \\
\left.\cdot \mathrm{sec}^{-1} \cdot \mathrm{deg}^{-1}\right)\end{array}$} & \multicolumn{2}{|c|}{$\begin{array}{l}A\left(\mathrm{cal} \cdot \mathrm{cm}^{-3}\right. \\
\left.\cdot \mathrm{sec}^{-1}\right)\end{array}$} & \multicolumn{2}{|c|}{$\begin{array}{l}E_{a}(\mathrm{kcal} \\
\left.\cdot \mathrm{mol}^{-1}\right)\end{array}$} \\
\hline $\begin{array}{l}\text { 掌 } \\
\text { 太 } \\
\text { 大 }\end{array}$ & $\begin{array}{l}\text { 磐 } \\
\text { 洋 } \\
\text { 張 }\end{array}$ & \multicolumn{2}{|c|}{$\begin{array}{l}3.0 \times 10^{-4} \\
2.7 \times 10^{-4} \\
2.6 \times 10^{-4}\end{array}$} & \multicolumn{2}{|c|}{$\begin{array}{l}2.4 \times 10^{-1} \\
6.0 \times 10^{2} \\
1.0 \times 10^{2}\end{array}$} & \multicolumn{2}{|c|}{$\begin{array}{r}5.5 \\
10.3 \\
10.3\end{array}$} \\
\hline \multicolumn{8}{|c|}{ 第 2 表 粒度分布測定結果 } \\
\hline \multirow[b]{2}{*}{ 粒径 } & & \multicolumn{2}{|c|}{ 常磐 } & \multicolumn{2}{|c|}{ 太平洋 } & \multicolumn{2}{|c|}{ 大夕 張 } \\
\hline & & $\begin{array}{c}\text { 重 } \text { 量 } \\
\end{array}$ & $\begin{array}{l}\text { 累積重 } \\
\text { 量 } \%\end{array}$ & \multicolumn{2}{|c|}{\begin{tabular}{|l|l} 
重量\% & $\begin{array}{l}\text { 累積重 } \\
\text { 量 } \%\end{array}$ \\
\end{tabular}} & \multicolumn{2}{|c|}{\begin{tabular}{c|c} 
重量 & 䍗積重 \\
量 $\%$
\end{tabular}} \\
\hline $\begin{array}{l}48 \sim 65 \mathrm{~m} \\
65 \sim 100 \\
100 \sim 150 \\
150 \sim 200 \\
-200\end{array}$ & $\begin{array}{l}\text { esh } \\
" \\
" \\
" \\
y\end{array}$ & $\begin{array}{l}12.5 \\
25.3 \\
16.2 \\
14.5 \\
31.5\end{array}$ & $\begin{array}{r}12.5 \\
37.8 \\
54.0 \\
68.5 \\
100.0\end{array}$ & $\begin{array}{l}15.7 \\
27.0 \\
14.3 \\
14.5 \\
28.5\end{array}$ & $\begin{array}{r}15.7 \\
42.7 \\
57.0 \\
71.5 \\
100.0\end{array}$ & $\begin{array}{r}18.6 \\
30.4 \\
15.4 \\
27.0 \\
8.6\end{array}$ & $\begin{array}{r}18.6 \\
49.0 \\
64.4 \\
91.4 \\
100.0\end{array}$ \\
\hline 訪 & & 100.0 & & 100.0 & & 100.0 & \\
\hline
\end{tabular}

基礎方程式(20)式を(21)，(22) 式の条件のもとに解く 場合に不可欠な定数值は，粉炭堆積体の体積比熱 $\left(S_{m}\right.$ $\left.\rho_{m}\right)$, 有効熱伝導率 $\left(\lambda_{e}\right)$, 定数 $(A)$, および見かけの活 性化エネルギー $\left(E_{a}\right)$ であるが，そのうち $\lambda_{e}, A, E_{a}$ に関 しては -48 mesh の粉炭に関して実測し, 第 1 表のとお りの結果を得ている ${ }^{1)}$ 。参考までに試料粉炭の粒度分布 測定結果を第 2 表に示す。
第 1 表 粉炭の有効熱伝導率 $\left(\lambda_{e}\right)$, 定数 $(A)$ 押よび 見かけの活性化エネルギー $\left(E_{a}\right)$ 測定結果

ここで粉炭の体積比熱 $\left(S_{m} \rho_{m}\right)$ に関して取り得る值の 範囲を検討すると, 石炭の比熱 $\left(S_{c}\right)$ に関しては多数の 測定がなされ，L.C. MCCABE および C. C. BolEY ${ }^{13)}$ よつてまとめられているが，一般に 0.2〜0.4 (cal·g ${ }^{-1}$ $\cdot{ }^{\circ} \mathrm{C}^{-1}$ ) 位の範囲にあるとされている。また石炭の密度 $\left(\rho_{c}\right)$ は置換物質に水またはヘリウムを用いて測定した結 果によれば ${ }^{14)} 1.2 \sim 1.5\left(\mathrm{~g} \cdot \mathrm{cm}^{-3}\right)$ 位である。空気の比熱 $\left(S_{f}\right)$ は $0.24\left(\mathrm{cal} \cdot \mathrm{g}^{-1} \cdot{ }^{\circ} \mathrm{C}^{-1}\right)$ 位, 密度は湿りの程度にもよ るが $1.2 \times 10^{-3}\left(\mathrm{~g} \cdot \mathrm{cm}^{-3}\right)$ 位である。先に述べたとおり粉 炭の体積比熱は $S_{m} \rho_{m}=S_{f} \rho_{f} \varepsilon+S_{c} \rho_{c}(1-\varepsilon)$ で表わさ れるから，常磐炭 $(C \fallingdotseq 78 \%)$ を例にとつて，空隙率 $(\varepsilon)$ をパラメータとして体積比熱を計算してみると第 3 表の とおりであり，ほぼ0.16〜0. $27\left(\mathrm{cal} \cdot \mathrm{g}^{-1} \cdot{ }^{\circ} \mathrm{C}^{-1}\right)$ 位の值と なることが予想される。以下の数值計算には空隙率 0.4 の時の值である0.23( $\left.\mathrm{cal} \cdot \mathrm{g}^{-1} \cdot{ }^{\circ} \mathrm{C}^{-1}\right)$ を粉炭の体積比熱と して使用した。

\section{$5 \cdot 5$ 計算結果}

電子計算機による計算結果の数例を第 2 図〜第 4 図に 示す。数值計算には東京大学大型計算機 HITAK-5020 ならびに北海道大学大型計算機 FACOM-230-60を使用 した。

\section{6. 計算結果に関する考察}

\section{$6 \cdot 1$ 粉炭の堆積体内部における蓄熱過程について}

第 2 図ほ常磐炭鉣の石炭を $48 \mathrm{mesh}$ 以下に粉砕し直径 $80 \mathrm{~cm}$ の球型に堆積して, 発熱に必要な酸素が供給され たと仮定した場合の蓄熱過程を示しているといえるが， 粉炭堆積体の表面温度が $40^{\circ} \mathrm{C}$ て定に保たれても，粉炭

第 3 表 空隙率 $(\varepsilon)$ と体積比熱 $\left(S_{m} \rho_{m}\right)$ の関係

\begin{tabular}{c|c|c}
\hline$\varepsilon$ & $1-\varepsilon$ & $S_{m} \rho_{m}\left(\mathrm{cal} \cdot \mathrm{g}^{-1} \cdot{ }^{\circ} \mathrm{C}^{-1}\right)$ \\
\hline 0.3 & 0.7 & 0.27 \\
0.4 & 0.6 & 0.23 \\
0.5 & 0.5 & 0.20 \\
0.6 & 0.4 & 0.16 \\
\hline
\end{tabular}




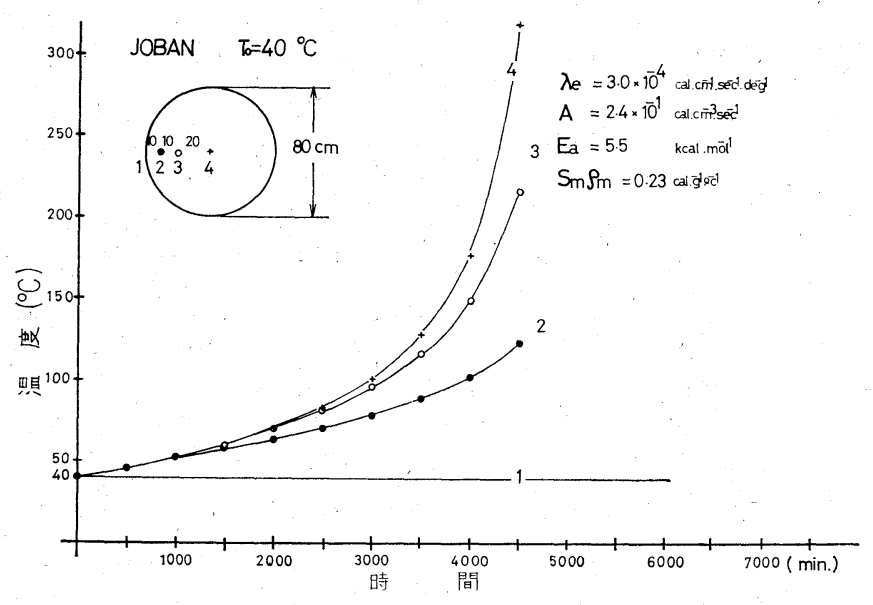

第 2 図 粉炭堆積体内部の温度変化の計算結果 (-48mesh 常磐炭)

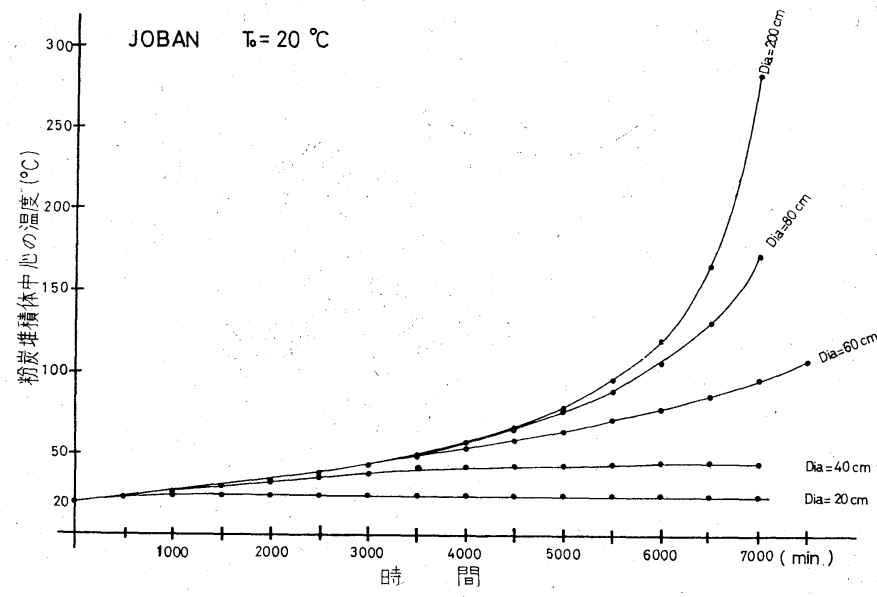

第3 図“粉炭堆積体（球型）の表面温度が $20^{\circ} \mathrm{C}$ の場合の蓄熱過程

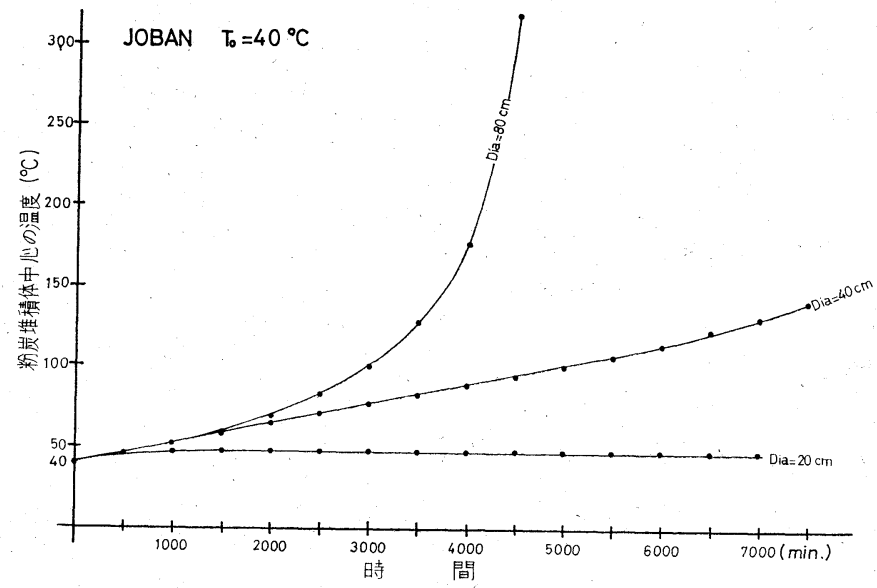

第4図 粉炭堆積体（球型）の表面温度が $40^{\circ} \mathrm{C}$ の場合の蓄熱過程

堆積体の内部では徐々に温度が上昇し，ほぼ75時間後に は堆積体の中心部で発火に至るという計算結果になつて いる。

$6 \cdot 2$ 自然発火し得る粉炭の限界量について

第 3 図は粉炭堆積体の表面温度が $20^{\circ} \mathrm{C}$ 場合, 第 4 図

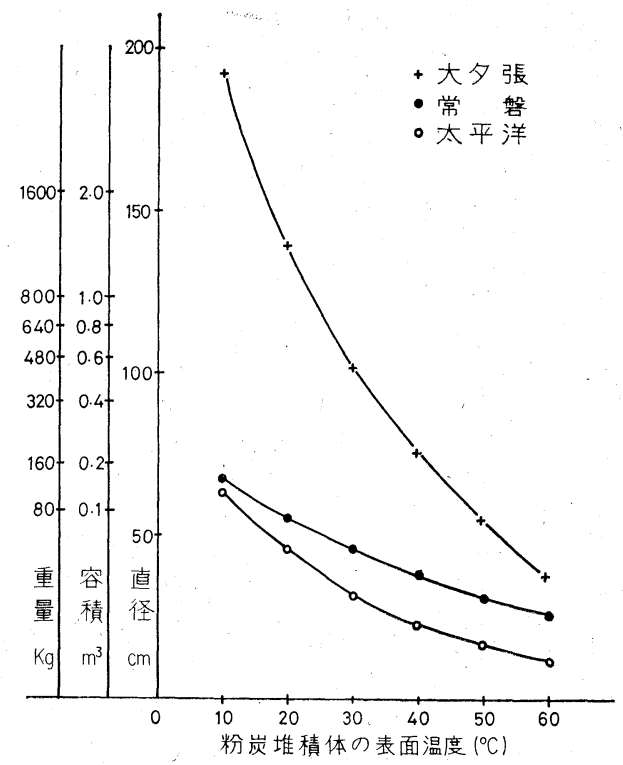

第 5 図表面温度と自然発火し得る粉炭量との関係

ほ $40^{\circ} \mathrm{C}$ の場合の計算結果であるが，両図の比較から粉 炭堆積体の表面温度が高くなるほど，少量の粉炭量で 発火し得ること，ならびにある表面温度では発火し得 ない限界量の存在することがわかる。

$48 \mathrm{mesh}$ 以下に粉䂗した常磐炭, 太平洋炭, 大夕張 炭に関して, 同様の計算方法で発火し得る粉炭量と， 発火し得ない粉炭量との限界を求めた結果を第 5 図に 示す。同図においては各曲線の上側が発火し得る範 囲，下側は発火し得ない範囲を示すことになる。なお 第 5 図の縦軸目盛における粉炭堆積体容積と重量との 換算は，炭種によつて異なるが，この場合近似的に 3 炭種の平均值で換算してある。

実際に自然発火を起こさせるためには，粉炭堆積体 内部における粉炭粒子や酸素などの反応物 質の消耗 や，通気の不均一性などの避けられない要因の影響が あるので計算上の限界量よりもある程度多量の粉炭が 必要であると考えられる。

\section{$6 \cdot 3$ 常磐炭, 太平洋炭, 大夕張炭の自然発火性 について}

第 5 図において，同じ表面温度で自然発火し得る粉 炭の限界量を 3 種類の石炭に関して観察すると, 太平 洋炭鉣の石炭が最も少量で自然発火し, 次に常磐炭鉣 の石炭，大夕張炭鉱の石炭の順に大量の粉炭を要する 結果になつている。少量の粉炭量で自然発火し得るこ とは，現場的にいつても自然発火性が大きいというこ とに連なるはずであるから，計算結果のみから判断する と, 太平洋炭, 常磐炭, 大夕張炭の順に自然発火性が強 いといらことになる。しかし実際には，太平洋炭鉱は国 内で自然発火のないことで代表的な炭鉱であり，常磐， 大夕張は自然発火の多いことで知られており矛盾があ 
る。このことは, 本研究における物性定数の測定が一定 粒度に粉砕した石炭に関して行なわれているために, 石 炭の破砕しやすさに関する影響が消去されてしまつてい ることにも起因しているものと考えられる。また各炭鉱 における地層温度の差も自然発火性に大きく影響してい るものと考えられる。つまり太平洋炭鉣の石炭のように 固い石炭でも砕いて常磐炭鉱のように坑内温度の高い所 へ持つて行けば, 自然発火し得るものと考えられる。

\section{$6 \cdot 4$ 石炭の粒度について}

第 5 図に打ける自然発火し得る粉炭の限界量は，あく までも第 2 表に示されるような粒度分布をもつ石炭に関 しての限界量であつて，これ以上の寸法を有する粉炭も しくは塊炭では，その酸化発熱量ならびに熱伝導率を測 定しなければ計算できないが，一般的にいつてさらに大 量の石炭の堆積が必要となると考えられる。

\section{参、考文 献}

1）伊木正二・桶口澄志：日本釷業会誌，89巻，1025号，昭和 48 年 7 月， 455 $\sim 460$ 真

2） S. M. Walas 著, 大竹层雄他訳 : 「化学技術者のための反応工学」丸善 株式会社, 昭和40年 7 月 15 日発行, 179 180頁

3）大竹伝雄著：「化学工学岩波全書255，1969年 3 月20日発行，140頁

4) W. Peters: Glückauf, 101, 1965 pp. 1526

5) P. Heusinger, H. MÜNZnER: Brennstoff-Chemie, 45, 1964, pp. 357

6) J. Langhoff, W. Peters: Erdöl und Kohle, 17, 1964, pp. 900

7) H. MÜnzNeR, W. Peters: Brennstoff-Chemie, 46, 1965, pp. 399

8）松本敬信 -中村昌二 : 北海道鉱山学会誌, 13, 1957, pp. 201

9) C. KRöger: Brennstoff-Chemie, 43, 1962, pp. 328

10) T. Kinbara, K. AKiтa: Combustion and Flame, 4, 1960, pp. 173

11) T. Kinbara, K. Akita: Publication 786, National Academy of Sciences. National Research Council, Washington, U.S.A. 1961, pp. $256 \sim 266$

12) P. L. Chambre: J. Chem. Phys., 20, 1952, pp. 1795

13) L. C. McCABE, C. C. BOLEY: 「Chemistry of Coal Utilization 1」 New York, 1945, Chapter 7

\section{Calculation of the Change of Temperature in the Heap of Powdered Coal and the Volume of Powdered Coal which Ignite Spontareously}

- Study on the mechanism of spontaneous combustion of coal at the temperature below $80^{\circ} \mathrm{C}$ (2nd Report) -

by Syōji IKI and Kiyoshi HIGUCHI

On the base of the hypothesis that the cause of spontaneous combustion of coal is the accumulation of heat produced by its oxidation, derived the equation expressing the temperature change in the heap of powdered coal.

To solve the equation numerically, thermal conductivity and rate of heat generation of powdered coal $(-48 \mathrm{mesh})$ were measured at various temperatures in the range of $20 \sim 65^{\circ} \mathrm{C}$ (1st Report).

Relationships between temperature and rate of heat generation could be expressed by means of the Arrheniuse's formula.

The equation for spherical co-ordinates was solved numerically and the volume of powdered coal which would ignite spontaneously was estimated, as the function of surface temperature.

The initial and boundary conditions used were as flloows,

(1) At the beginning of the course, temperature distribution in the heap of powdered coal is uniform.

(2) Surface temperature of the heap of powdered coal remains constant during the course. 